\title{
På afgrundens rand
}

\section{Rasmus Glenthøj}

\section{4 - året hvor Danmark blev en småstat. Om danskernes store og glorværdige nederlag}

Hvis man ikke kan få det, man elsker, må man elske det, man har fået. Til næste år kan Danmark således med pomp og pragt fejre ikke blot et, men hele to store og glorværdige nederlag. Ved skæbnens ironi er 2014 både 150-året for nederlaget i 1864 og 200-året for 'tabet af Norge'.

Der er imidlertid et misforhold i betydningen, som de to årstal traditionelt er blevet tillagt.

Året 1864 er mejslet ind i dansk selvforståelse. Hvis man skal forklare noget om Danmark, så henviser man blot til dette årstal, der tjener som en form for universalforklaring på alt. Det er ikke uden grund. Tusinder faldt, drømmen om Danmark til Ejderen brast, og staten blev, hvis man ser bort fra bilandene i Nordatlanten og sukkerøerne i Caribien, en nationalstat.

Historien vil samtidig vide, at det var her, at Danmark blev en småstat og småstatsmentaliteten opstod. Dette sidste er imidlertid en misforståelse, som vi skal vende tilbage til.
1814, derimod, har stået i 1864's skygge. Det er paradoksalt, da 1814 uden sammenligning er det største territorielle, økonomiske og ressourcemæssige tab i statens historie, mens året må dele sejrsskamlen med 1864, når det gælder det største befolkningsmæssige tab. Den vigtigste årsag til dette misforhold er, at mens 1864 var et nationalt nederlag, der efterlod 200.000 dansksindede slesvigere syd for den nye grænse, så var 1814 en dynastisk og statsligt katastrofe.

1814 passer hermed ikke ind i det nationale narrativ, der har præget dansk historieskrivning siden 1800tallet. Historiefaget blev professionaliseret i kølvandet på de prøjsiske bank, som landet fik i 1864. De første professionelle historikere tilhørte dermed den første generation, der var opvokset i en nationalstat. Det fik dem til at overføre denne på en fortid, hvor staten hverken var lille eller national. Denne historiske arvesynd har præget danskerne lige siden og i sandhed gjort fortiden til 
et fremmed land. Med hvad skete der egentlig i 1814 og hvad betød det?

Tre gange i historien har den danske stats eksistens reelt været på spil. Den første gang var under den kongeløse periode i 1330'erne, den anden var under svenskerkrigene 1657-1660, og den tredje gang var i 1814. Her slog den svenske kronprins, Karl Johan, Danmarks bagdør ind og besatte hertugdømmerne. Hans officielle krav var afståelsen af Norge, men overfor sine allierede fremlagde han den ene efter den anden plan for at sønderlemme hele den danske stat. Sverige ønskede sig Sjælland, mens Jylland enten kunne blive til et selvstændigt 'kimbrisk' rige eller blive indlemmet i Prøjsen eller en anden nordtysk stat.

Fred for enhver pris var nødvendig, og Frederik den Sjette valgte derfor at bryde kongeloven og afstå sit norske rige til den svenske arvefjende. Som et plaster på amputationen af Norge gav Sverige den danske stat Svensk Pommern. Danmark bibeholdte dog de tre oprindeligt norske bilande, Grønland, Island og Færøerne. Historien har lige siden gået, at det var den snu danske forhandler, der tog sin svenske modpart ved næsen. Senere opstod myten om, at det skyldtes britisk indblanding. Sandheden er, at årsagen til man i dag i Danmark kan diskutere storskalalov, uran og olie i Grønland, er, at Karl Johan i 1814 eksplicit bad om Fastlandsnorge.
Med Freden i Kiel skulle man tro, at den hellige grav var vel forvaret. Men i Norge rejste den danske tronfølger Christian Frederik oprørsfanen i den norske nations navn.

Svenskerne slog bak, da de ikke helt uden grund mistænkte danskerne for slet spil. Det fik Prøjsen og Spanien til at nægte Danmark fred, mens Storbritannien og Rusland afviste at ratificere de aftaler, der var indgået. Imperiets skæbne var stadig på spil, og Frederik den Sjette måtte med hatten i hånden drage til Wien, hvor kontinentets fyrster samledes for at skabe et nyt Europa.

\section{Tabet af Norge}

Det danske imperiums enehersker var imidlertid ikke kun truet af russiske kosakker i hertugdømmerne, en intrigant Karl Johan og en uafsluttet krig med det meste af Europa. Tronen valkede også under Frederik. Den danske elite var forbundet med nordmændene gennem sprog, kultur, familie, uddannelse og økonomi. 1814 var ikke kun et chok og en fundamental omvæltning. Året skabte hos dannede danskere sorg, skam og en bitterhed vendt mod monarken og hans rådgivere, der blev givet ansvaret for katastrofen. Men modsat 1864, så forhindrede censuren offentligheden i at udtrykke sine holdninger frit.

Danskerne støttede fuldt og fast 'den norske sag' og drømte sødt om tvillingerigernes genforening. Chri- 
stian Frederik blev set som en romantisk helt, der ledte et helt folks frihedskamp, mens danskerne på tværs af landsdele og sociale lag vendte Frederik den Sjette ryggen. Allerede før Freden i Kiel blev der sat spørgsmålstegn ved enevælden. Med henvisning til, at riget var rystet i sin grundvold, skrev grev HolsteinHolsteinborg ved nytår 1814 en skitse til en fri dansk forfatning. Den gode greve var i disse måneder ikke alene i dette ønske, der blev forstærket af begivenhederne i Norge. Fra svensk side forsøgte man få fjernet den oprørske prins fra den danske arvefølge. Men selvom Danmarks overlevelse stod på spil veg monarken tilbage. Kongen frygtede for revolution i en hovedstad, hvor man diskuterede at afsætte Frederik til fordel for den norske frihedshelt. København var i denne tid fyldt med løbesedler, der krævede en ytringsfrihed og en fri forfatning.

\section{Danskere mere danske}

Imperiets nye miniputstatus medførte en metamorfose for den danske selvforståelse. Man vendte sig indad og forsøgte at generobrede Norge i Danmark ved at opbygge en ny åndelig selvrespekt og selvhævdelse. Mens staten skrumpede så voksede nationalfølelsen. Mænd som grev Holstein-Holsteinborg forsøgte efter det ydmygende nederlag at revitalisere nationen politisk, men her spærrede Frederik den Sjette med de konservative stormagter i ryggen effektivt vejen frem.

Den ånd, der opstod i 1814, kom derfor i stedet til udtryk igennem en kulturnationalisme, hvor kunstnere, intellektuelle og videnskabsmænd forsøgte at genrejse og genføde nationen. Slægten fra 1814 var præget af nederlaget og for den gjaldt det at sikre nationens overlevelse og selvstændighed. Folket måtte ligne sig selv, ikke efterabe andre, men lære sig selv at kende. Som sande romantikere søgte man tilbage i historien for at finde forbilleder og et fundament for nationen.

Ligesom på resten af kontinentet, var disse kulturelle reformatorer konservative, men deres idéer om nationen kom til at bane vejen for en ny opfattelse af folket. De konservatives opgør med 1700-tallets kosmopolitiske tanker til fordel for dansk-nordisk nationalopdragelse fik dramatiske konsekvenser, da den yngre liberale generation i 1830 'erne byggede deres politiske forestillinger om folket på de konservatives kulturnationalisme. Når eliten i en multinationalstat, som den danske, kombinerer liberalisme med nationalisme, så er den dømt til at dø. Ånden fra 1814 førte i fællesskab med statens demokratisering til Dybbøl og Als.

I et europæisk perspektiv spillede Danmark en statistrolle på Wienerkongressen, men fra et dansk synspunkt var det afgørende at være til stede, da det europæiske pulsespil 
blev lagt. Allerede før kongressen åbnede, så situationen lysere ud. Briterne havde ratificeret Freden i Kiel, ligesom man fik fred med Prøjsen mod at afstå det nyerhvervede Pommern til fordel for miniputhertugdømmet Lauenborg og klingende mønt i den gabende tomme danske statskasse.

I Wien var fire ting på spil. For det første at få russerne til at ratificere freden mellem de to lande og rømme hertugdømmerne, da besættelsen udpinte folket og truede staten. For det andet at tvinge Sverige til at leve op til dets forpligtelser. For det tredje at forhindre, at det danske imperium, som det skete med andre af Napoleons allierede, blev parteret eller opslugt. For det fjerde at varetage statens interesser i forhold til nyordningen af Tyskland, som imperiet gennem Holsten var en del af.

På trods af store vanskeligheder, så lykkedes det at komme i hus med alle fire mål. Frederik den Sjettes personlige tragedie, stormagternes interesse i at bibeholde en lille magtesløs stat ved Østersøens indsejling og i at forhindre Prøjsen i at få den fremragende havn i Kiel sikrede det amputerede miniputimperium dets eksistens.

\section{Miniputimperiet}

Afståelsen af det gigantiske Norge gjorde geografisk set Danmark til Napoleonskrigenes største taber. I et Europa, hvor der var blevet færre og større stater, var den danske stat skrumpet både befolkningsmæssigt, territorielt, militært og økonomisk. Det danske miniputimperium var nu som Gullivor i kæmpernes land, hvor det gjaldt om ikke at blive trådt på. Omvendt betød adskillelsen fra Norge, at den danske stat blev mere kompakt, og hermed lettere at forsvare, end den tidligere havde været.

Kontrasten til den danske stat før Napoleonskrigene, hvor økonomien havde boomet i den florissante periodes København, kunne dårligt være større. Staten havde været en stat af anden rang, der i et vist omfang kunne føre en selvstændig politik. Efter 1814 var Danmark en stat af fjerde rang, der udelukkende levede på stormagternes nåde. Dette skyldtes ikke alene det enorme tab af territorium, befolkning og ressourcer, men også tabet af flåden i 1807 , der tidligere havde gjort Danmark til en attraktiv allieret. Ondt blev til værre, da staterne omkring Danmark fik vokseværk. Den gamle diplomat Georg Rist sagde slående, at den danske stats udenrigspolitik var, at man ikke havde nogen udenrigspolitik.

Heri havde han ret. Udenrigspolitisk var det den kurs, som Danmark førte, da alle erkendte, at staten intet formåede ved magt, men måtte indrette sig efter det store udland. Kræfterne måtte i stedet samles indadtil. Ideen om at erobre den jyske hede som kompensation for det 
ydre tab, blev allerede lanceret og iværksat i årene efter 1814. Håbet om en genforening med Norge levede i de første år, men det var kun fantaster, der drømte om militær genrejsning og krig mod Sverige. Den danske stat var blevet en småstat med en tilhørende småstatsmentalitet.

Statens befolkning var faldet til halvanden million, hvoraf en lille million boede i Kongeriget. Den tilbageværende dansk-tyske stat er gået over i historien som helstaten, hvilket glimrende indfanger den politik, som regeringen forsøgte at føre. Nemlig en politik, der ønskede at holde hele staten samlet. Enevældens statsmænd tænkte hverken nationalt eller regionalt, men ud fra den samlede statsdannelse.

Før 1814 havde danskerne og nordmændene tilsammen udgjort et flertal på 75 procent af statens befolkning, der var dansksproget og nordisk. Frederik den Sjette så sin stat som en skandinavisk stat og havde netop derfor afvist et russisk tilbud om at bytte Norge til fordel for store dele af Nordtyskland og Holland. I 1814 blev det 'nye' Norden skabt; spørgsmålet var blot hvor Danmark hørte til. Med 'tabet af Norge' og tildelingen af Lauenborg blev det indbyrdes dansk-tyske forholds styrke forrykket. Nu var 60 procent dansktalende og 40 procent tysktalende. Staten var blevet gumpetung, da de økonomisk udviklede hertugdømmer trak mod syd på et tidspunkt, hvor nationalitet blev givet en ny betydning. Ondt blev til værre, da mange i det nye Norge på bedste postkoloniale vis ønskede at gøre op med den fælles fortid og kultur. Danskerne måtte stå på egne ben uden at holde nordmændene i hånden.

'Tabet af Norge' betød, at den københavnske elite måtte orientere sig på ny. Når den tidligere, nødtvunget, havde set ud over byens volde, havde den set mod Norge. Det gik ikke længere. Skilsmissen betød, at københavnerne begyndte at forholde sig til det terra incognita, som befandt sig hinsides Valby Bakke. 1814 medfødte 'opdagelsen af Jylland' og integrationen af det danske 'Sibirien'.

\section{Det Tyske Forbund}

Et af Wienerkongressens mål var at skabe et nyt og stærkere tysk forbund. Holsten havde været en del af det tysk-romerske rige, der i 1806 blev et offer for Napoleons støvletrampen. Frederik den Sjette greb muligheden og indlemmede Holsten i Danmark i et forsøg på at skabe et Stordanmark med dansk som statssprog. I dette forsøg på 'danisering' glemte man ikke Holsten. I 1814 stod det klart, at det var urealistisk at holde Holsten uden for det nye Tyskland. Det danske imperium havde tabt og måtte indordne sig.

På kongressen i Wien skabte man ud af det tyske kaos et forbund på 
39 stater. Formålet var at skabe ro og stabilitet i Centraleuropa samt en effektiv 'buffer' mellem Rusland og Frankrig. Men ligesom sin forgænger blev Det Tyske Forbund lammet af staternes særinteresser og rivaliseringen mellem $\emptyset$ strig og Prøjsen. Holstens og Lauenborgs medlemskab gav på kort sigt den danske stat sikkerhed. Forbundet var ikke blot en politisk diskussionsklub, men også et forsvarsforbund. Grænsen mod syd synes hermed sikret, ligesom medlemskabet kunne afholde Karl Johan fra lave en 'Karl Gustav' og forsøge at fjerne Danmark fra Europakortet. På længere sigt havde medlemskabet imidlertid to utilsigtede, men afgørende konsekvenser. Alle forbundets fyrster forpligtede sig til at give deres folk en stænderforfatning, dvs. et begrænset politisk medborgerskab. Det var dette, der i 1831 tvang Frederik den Sjette til at give ikke blot Holsten, men hele staten stænderforsamlingerne. Tyskland spillede således en stor rolle i demokratiseringen af Danmark.

Omvendt gav Holstens medlemskab forbundet ikke alene ret, men også pligt til at blande sig i den danske stats indre anliggender for at beskytte statens tyske borgere. Forbundet lagde snævre grænser for den danske stats handlefrihed og begrænsede dens suverænitet, hvilket i høj grad kom til at spille en rolle i 1848 og 1864.

I Napoleonskrigenes kølvand hånede selv Batavias skrantende kræm- mere Danmark 'som et lident, fattigt land'. Statens skuldre var bristet under Napoleonskrigenes åg, og i 1813 gik staten bankerot.

\section{Depression}

Freden udløste en krise, der kastede hele kontinentet ud i en depression, der lammede økonomien frem til 1830. Man forsøgte at genopbygge handelsflåden, men tiderne havde ændret sig. Tidligere havde man levet højt på neutralitet $\mathrm{i}$ en verden $\mathrm{i}$ krig. Nu var handlen fri og freden sikret, hvilket oversvømmede markedet med varer. Det fik mange handelsmænd til at nære et fromt ønske om nye krige, hvor Danmark som dødens købmand på ny kunne spinde guld på andres ulykke. Dette skete imidlertid ikke. De store handelshuse krakkede, hvilket skabte en $\varnothing$ konomisk dødsspiral i dansk erhvervsliv.

Hovedstaden og hertugdømmerne, der sejlede på de internationale ruter, blev hårdest ramt, mens den del af provinsen, der forsynede København eller sejlede på Vesteuropa slap billigere. Nogle provinsbyer blev direkte styrket af Københavns svækkelse, mens Nordjylland, der traditionelt havde forsynet Norge med korn, blev lammet. Aalborg, der havde været Danmarks næststørste by, rejste sig aldrig til samme rang efter "tabet af Norge". København gik fra at være et nordeuropæisk handelscentrum til landets stør- 
ste provinsby. Hamborg overtog ikke alene hovedstadens internationale ruter, den blev også et centrum for industri og udlån, der trængte sig ind på Københavns hjemmemarked.

$\varnothing$ konomisk var 1814 et næsten dræbende slag, som det tog hovedstaden mere end 50 år at komme sig over. En af årsagerne var, at handlen på Vestindien, hvorfra man fik sukker, kollapsede med introduktionen af sukkerroen i Europa. Det ruinerede ikke alene københavnske købmænd, men også mange plantageejere på de danske øer i Caribien. De vestindiske øer havde engang været juvelen i den danske krone, nu blev øerne til en fattiggård, og et tilbagevendende økonomisk problem frem til 1917.

En medvirkende årsag til den økonomiske katastrofe var pengepolitikken. Statsbankerotten var en pengeombytning, hvor de eksisterende sedler blev nedskrevet til $10 \%$ af det pålydende, mens der blev lagt et loft over udstedelsen af nye sedler. Ved ombytningen blev mængden af sedler reduceret med 5/6. Målet med var at skabe et fælles pengesystem i staten og stoppe den galoperende inflation. En del af problemet ved pengereduktionen var, at den byggede på en forudsætning om, at krigen snart var over. Napoleon var blevet besejret i Rusland, og fra dansk side sendte man fredsfølere til Storbritannien.

Krigen var imidlertid langt fra færdig, tværtimod blev staten tvun- get til en mere aktiv deltagelse, der belastede finanserne til det yderste. Tiltroen til og kursen på de nye sedler faldt med raketfart. I hertugdømmerne, hvor man indtil 1813 havde haft sin egen stabile sølvvaluta, ville man slet og ret ikke acceptere de nye pengesedler, og regeringen måtte modstræbende lade hertugdømmerne stå uden for reformen. 'Tabet af Norge' gjorde kun tingene værre, da seddelmængden havde været beregnet på staten anno 1813 . Dermed faldt kursen yderligere.

Situationen blev forbedret i årene efter freden, men i 1818 brød det europæiske kornmarked sammen under en uhellig alliance af britisk protektionisme, øget udbud, mindre efterspørgsel og tabet af det norske hjemmemarked. Den danske stat fulgte slavisk et mål om at kursen gik i pari, hvilket fik den nye nationalbank til at tage så mange pengesedler ud af cirkulation som muligt. Resultatet blev en kronisk pengemangel for dansk erhvervsliv. Operationen lykkedes i 1838, men patienten, det danske erhvervsliv, var for længst afgået ved døden.

Situationen blev forværret, da industrien, der havde været beskyttet fra konkurrence, blev udfordret af engelske produkter, som de danske ikke kunne måle sig med. Fabrikker gik ned på stribe, omend produktionen på nogle områder stabiliserede sig på et niveau, der lå over det, som det havde været før krigsudbruddet. Priserne på jord faldt som en sten - 
i Jylland ned til en 1/10. Staten forsøgte at hjælpe landbruget med lån, der byggede på regeringens egne lån i udlandet, ligesom skatterne blev sænket. Men krisen fortsatte, godserne gik konkurs og staten endte med en enorm mængde jord. Lidt efter lidt tilpassede man omkostningsniveauet på landet $\mathrm{og} \mathrm{i}$ 1828 ophævede briterne delvist deres kornlove, hvilke fik priserne til at stige. Hertil kom, at befolkningen på kontinentet begyndte at vokse hurtigere end kornproduktionen.

\section{En skjult velsignelse?}

Krigen og den efterfølgende krise medførte ikke blot et økonomisk kollaps, men også et moralsk sammenbrud i embedsmandsstanden. Den havde fået udhulet sine faste lønninger af hyperinflation, hvilket skubbede den enkelte embedsmands økonomi ud over afgrunden og det underminerede befolkningens tillid til staten. I den kritiske situation greb kongemagten resolut ind. Alle sager om embedsmisbrug blev undersøgt, og i de tilfælde hvor den formastelige ikke kunne betale tilbage risikerede han fængsel på livstid. Systemet blev sanneret, reglerne klargjort, lønningerne hævet og lovgivning forberedt. Paradoksalt håndterede den danske enevælde hermed korruptionen bedre end det frie Norge, hvor embedsmænd, der havde fået magten i 1814, dækkede over hinanden.

1814 var en katastrofe. Spørgsmålet er, om året også var en skjult velsignelse? For danske historikere har svaret lige siden Grundtvig i 1831 været et ubetinget ja. Nordmændene fik deres frihed, uden at det krævede en lang og opslidende frihedskamp fra Danmark, der kunne have skabt et varigt had. Meget taler for, traditionen har ret. Den centralistiske, enevældige stat kunne umuligt have holdt på Norge. Omvendt er denne fortolkning præget af vores viden om, hvad der skete efter 1814 .

Den senere udvikling af de nordiske nationalstater og den nationale identitet, som vi kender dem, var imidlertid ikke teleologisk. Før 1814 ønskede den norske elite ikke løsrivelse, men en føderation og en fri forfatning. Selv i 1814 var flertallet åbent for en genforening med Danmark på lige vilkår. Ligesom vores samtid ikke er deterministisk bestemt, så var fortidens fremtid åben.

Mest interessant er historien om den siden latterliggjorte skandinavisme, der meget let kunne være gået anderledes, men det er en helt anden artikel!

Rasmus Glenthøj er historiker, ph.d. 